\title{
PRESENCE OF STAPHYLOCOCCUS SPP. AND CANDIDA SPP. IN THE HUMAN ORAL CAVITY
}

\author{
Clélia Aparecida de Paiva Martins ${ }^{1 *}$; Cristiane Yumi Koga-Ito ${ }^{1}$; Antonio Olavo Cardoso Jorge ${ }^{1,2}$ \\ ${ }^{1}$ Departamento de Biociências e Diagnóstico Bucal da Faculdade de Odontologia, Universidade Estadual Paulista, Campus de \\ São José dos Campos, São José dos Campos, SP, Brasil. ${ }^{2}$ Departamento de Odontologia, Universidade de Taubaté, \\ Taubaté, SP, Brasil
}

Submitted: October 05, 2001; Returned to authors for corrections: February 27, 2002; Approved: August 30, 2002

\begin{abstract}
The presence of yeasts and staphylococci in the oral cavity is important because they can act as supplementary microbiota and in certain situations can cause oral or systemic diseases. The aim of this work was to study the prevalence of Candida spp. and Staphylococcus spp. in the human oral cavity. Oral rinses were collected from sixty-eight individuals according to the technique described by Samaranayake and MacFarlane and then cultured on Sabouraud medium supplemented with chloramphenicol and Baird-Parker agar. After the incubation period, the microorganisms were isolated and identified through biochemical tests. The data obtained were statistically analysed by ANOVA. Candida spp. were isolated from $61.76 \%$ of the examined individuals and C. albicans was the more frequently isolated specie. Staphylococcus spp. were isolated from $95.60 \%$ of the individuals and 41 strains were coagulase negative (63\%). Among the coagulase positive strains, nine were $S$. aureus, 11 S. hyicus and 4 S. schleiferi subspecie coagulans. No correlation was observed between the counts (cfu) of the isolated Candida spp. and Staphylococcus spp.
\end{abstract}

Key words: Staphylococcus, Candida, phospholipase, proteinase, killer system, oral cavity.

\section{INTRODUCTION}

Candida spp. and Staphylococcus spp. are usual in the human oral microbiota. However, in some situations, as in patients with periodontitis under systemic administration of penicillin and erythromycin, they can act as opportunistic microorganims and produce superinfection (7).

C. albicans is considered the main etiologic agent of candidosis, an opportunistic infection, related with local and systemic predisposing factors $(2,4,15)$. Candidosis is commonly found in the palate of total denture users, median rhomboid glossitis, immunocompromised patients and those in treatment with antibiotics $(3,26)$. Staphylococcus aureus is an important human pathogen and produce several diseases, including fatal systemic and opportunistic diseases and urinary tract infections (28). Other species of Staphylococcus are also related to several opportunistic infections in man and other animals.
The aim of this work was to study the prevalence of Candida spp. and Staphylococcus spp. in the human oral cavity, and to identify the species of Candida and coagulase positive Staphylococcus. Proteinase and phospholipase activities evaluation and the classification of Candida spp. strains through killer system were also performed.

\section{MATERIALS AND METHODS}

Sixty-eight individuals aged between 25 to 55 years old (34.45 \pm 7.93), from the dental clinics of the School of Dentistry São José dos Campos/UNESP, were studied. They were informed about the aim of the research and about the oral rinses collection. All the patients signed an authorization letter. This project was submitted and approved by the Bioethic Commitee of the School of Dentistry São José dos Campos/UNESP, SP, Brazil. Each patient was examined for just one examiner.

\footnotetext{
* Corresponding author: Mailing address: Departamento de Biociências e Diagnóstico Bucal, Faculdade de Odontologia de São José dos Campos UNESP, Av. Eng. Francisco José Longo, 777. 12245-000, São José dos Campos, SP, Brasil. FAX (+5512) 3921-2036, Phone: (+5512) 3921-8166. Email: clelia@fosjc.unesp.br.
} 
Individuals included those that did not present caries lesions or periodontal diseases and also those without orthodontics appliances and total or partial dentures. These patients did not relate any systemic disease or use of antibiotics during the six months that preceeded the collection of the oral rinses.

Oral rinses (60 seconds) were collected in $10 \mathrm{ml}$ of sterile phosphate-buffered saline (PBS, 0.1M, pH 7.2) supplied in universal containers. In a maximum period of 3 hours after sampling, oral rinses were centrifuged at $3.000 \mathrm{xg}$ and the supernatant was discharged. The final suspension was obtained by resuspending the deposit in $2.5 \mathrm{ml}$ of PBS (0.1M, pH 7.2). Then, aliquotes of $0.1 \mathrm{ml}$ of this sample were cultured in duplicates on Sabouraud agar (Difco, Detroit, USA) supplemented with chloramphenicol $(0.1 \mathrm{mg} / \mathrm{ml})$ and on Baird-Parker agar (Difco, Detroid, USA). Plates were incubated at $37^{\circ} \mathrm{C}$ for 48 hours. The samples were also cultured on CHROMagar Candida (CHROMagar, Paris, France).

After the incubation period, the cfu (colony forming units) were counted. Microscopic confirmation was performed from each plate. Five yeasts colonies were subcultured on Sabouraud agar and five colonies of staphylococci were subcultured on TS agar (Triptic Soy agar, Difco, Detroit, USA).

The yeasts strains were identified by growth on CHROMagar and by germ tube test, hyphae/pseudohyphae and chlamidospores growth, carbohydrate fermentation and assimilation according to Samaranayake and MacFarlane (26) and Sandvén (27). After the identification, proteinase and phospholipase activities were evaluated. Samples were also classified according to killer system (22).

Phospholipase production was evaluated according to Price et al. (23). Proteinase production test was performed according to Rüchel et al. (24).

Proteinase and phospholipase activities were determined by measuring the colony and the precipitation zone according to Price et al. (23).

Staphylococci isolates were identified biochemically through coagulase, Voges Proskauer, D-threalose fermentation and betagalactosidase tests according to Forbes et al. (5). S. aureus ATCC 6538 and E. coli ATCC 8739 beta-galactosidase positive were used as positive control.
The data were analysed statistically using ANOVA. Differences were considered statistically significant when $\mathrm{p} \leq$ 0.05 .

\section{RESULTS}

The distribution of the patients positive to Candida spp. and Staphylococcus spp. according to their age is presented in Table 1.

Candida spp. were isolated from 42 individuals (61.76\%). C. albicans was the most frequently isolated specie, followed by $C$. tropicalis $(20.42 \%), C$. glabrata $(6.12 \%)$ and $C$. kefyr (2.04\%) (Table 2).

Staphylococcus spp. were isolated from 65 individuals (95.60\%). Among these isolates 41 (63\%) were coagulase negative. From the 24 coagulase positive isolates nine were $S$. aureus, 11 S. hyicus and 4 S. schleiferi subspecie coagulans (Table 3).

No correlation $\left(\mathrm{R}^{2}=1.2 \%\right)$ between the cfu of Candida spp. and Staphylococcus spp. was observed (Fig. 1).

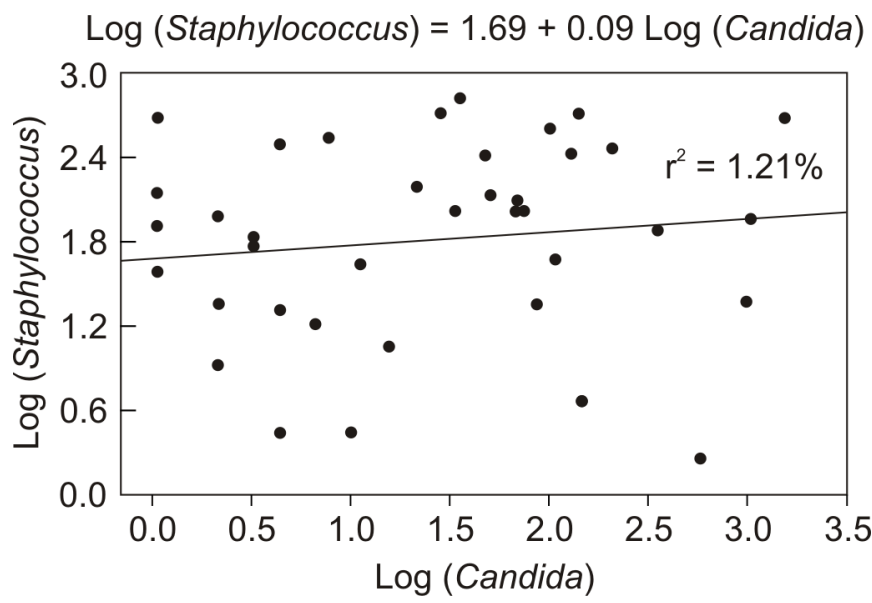

Figure 1. Dispersion diagram, regression line and correlation coeficient between the logarithm of cfu values of Staphylococcus and Candida genus isolated from human oral rinses.

$\log =\log$ arithm $\mathrm{cfu}$ (logarithm colonies forming units).

Table 1. Distribution of the patients positive to Candida spp. and Staphylococus spp. according to their ages.

\begin{tabular}{cccccc}
\hline Age & $\begin{array}{c}\text { Total of } \\
\text { patients } \\
\text { (n) }\end{array}$ & $\begin{array}{c}\text { Number and \% Candida } \\
\text { spp. positive patients in } \\
\text { relation to the total of } \\
\text { patients }\end{array}$ & $\begin{array}{c}\% \text { of Candida ssp. } \\
\text { positive patients } \\
\text { according to the } \\
\text { ages }\end{array}$ & $\begin{array}{c}\text { Staphylococcus spp. positive } \\
\text { patients in relation to the total } \\
\text { of patients }\end{array}$ & $\begin{array}{c}\text { ssp. positive patients } \\
\text { according to the ages }\end{array}$ \\
\hline $25-35$ & 45 & $29(42.65 \%)$ & 64.44 & $43(63.24 \%)$ & 95.56 \\
$36-45$ & 20 & $10(14.70 \%)$ & 50 & $19(27.94 \%)$ & 95 \\
$46-55$ & 3 & $3(4.41 \%)$ & 100 & $3(4.41 \%)$ & 100 \\
\hline Total of patients & 68 & $42(61.66 \%)$ & & $65(95.59 \%)$ \\
\hline
\end{tabular}


Table 2. Number (n) and percentage (\%) of the species of Candida isolated from the studied individuals.

\begin{tabular}{lcc}
\hline \multicolumn{1}{c}{ Species } & $\mathrm{n}$ & $\%$ \\
\hline C. albicans & 30 & 61.22 \\
C. tropicalis & 10 & 20.42 \\
C. glabrata & 03 & 6.12 \\
C. kefyr & 01 & 2.04 \\
Candida spp. & 05 & 10.20 \\
\hline Total of species & 49 & 100 \\
\hline
\end{tabular}

Table 3. Number (n) and percentage (\%) of the species of Staphylococcus isolated from the studied individuals.

\begin{tabular}{lcc}
\hline \multicolumn{1}{c}{ Species } & $\mathrm{n}$ & $\%$ \\
\hline S. aureus & 09 & 13.9 \\
S. hyicus & 11 & 17.0 \\
S. schleiferi** & 04 & 6.1 \\
Staphylococcus spp. $^{*}$ & 41 & 63.0 \\
\hline Total & 65 & 100 \\
\hline
\end{tabular}

* Coagulase negative; ** subspecie coagulans.

Table 4. Frequency of killer biotypes and enzymatic activity of the Candida spp. isolates studied.

\begin{tabular}{|c|c|c|c|c|c|c|c|c|}
\hline \multirow[t]{2}{*}{ Species } & \multirow{2}{*}{$\begin{array}{c}\text { Biotypes } \\
\text { killer }\end{array}$} & \multirow[t]{2}{*}{$\mathrm{n}$} & \multicolumn{3}{|c|}{$\begin{array}{l}\text { Phospholipase } \\
\text { activity }\end{array}$} & \multicolumn{3}{|c|}{$\begin{array}{l}\text { Proteinase } \\
\text { activity }\end{array}$} \\
\hline & & & 1 & 2 & 3 & 1 & 2 & 3 \\
\hline \multirow[t]{6}{*}{ C. albicans } & 111 & 18 & 0 & 8 & 10 & 0 & 5 & 13 \\
\hline & 114 & 03 & 2 & 0 & 1 & 0 & 1 & 2 \\
\hline & 116 & 01 & 0 & 0 & 1 & 0 & 1 & 0 \\
\hline & 411 & 03 & 1 & 0 & 2 & 0 & 0 & 3 \\
\hline & 443 & 01 & 0 & 0 & 1 & 0 & 0 & 1 \\
\hline & 888 & 04 & 1 & 1 & 2 & 1 & 1 & 2 \\
\hline Total & & 30 & 4 & 9 & 17 & 1 & 8 & 21 \\
\hline \multirow[t]{3}{*}{ C. tropicalis } & 111 & 05 & 1 & 2 & 2 & 1 & 3 & 2 \\
\hline & 114 & 03 & 1 & 1 & 1 & 1 & 1 & 1 \\
\hline & 888 & 02 & 1 & 0 & 1 & 1 & 0 & 1 \\
\hline Total & & 10 & 4 & 3 & 4 & 3 & 4 & 4 \\
\hline \multirow[t]{2}{*}{ C. glabrata } & 111 & 02 & 0 & 1 & 1 & 0 & 2 & 0 \\
\hline & 114 & 01 & 0 & 0 & 1 & 1 & 0 & 0 \\
\hline Total & & 03 & 0 & 1 & 2 & 1 & 2 & 0 \\
\hline C. kefyr & 111 & 01 & 1 & 0 & 0 & 1 & 0 & 0 \\
\hline \multirow[t]{2}{*}{ Candida spp. } & 111 & 01 & 4 & 0 & 0 & 0 & 1 & 0 \\
\hline & 114 & 04 & 1 & 0 & 0 & 4 & 0 & 0 \\
\hline Total & & 05 & 5 & 0 & 0 & 4 & 1 & 0 \\
\hline
\end{tabular}

Enzymatic activities: $1=$ negative, $2=$ positive, $3=$ strongly positive.
The most frequently isolated killer biotype observed among the studied strains was the 111 (60\% of the strains) followed by the biotype $114(10 \%)$ (Table 4). Eighteen $(60 \%)$ of the $C$. albicans isolates produced phospholipase and 18 (60\%) showed proteinase activity. C. kefyr strain did not produce phospholipase and proteinase.

Among the 68 individuals, $39(57.35 \%)$ presented both studied microorganisms in the oral cavity. Five individuals (7.14\%) presented $C$. albicans and $S$. aureus in the oral rinses but no correlation between the ufc of these species was observed.

\section{DISCUSSION}

Öhman and Jontell (16) observed an association between $C$. albicans and $S$. aureus in a case of angular cheilitis. In the present study, no correlation between the presence of the two genus was observed. However, in this study no individuals presented angular cheilitis or other oral lesions suggesting candidosis or staphylococci infection.

The literature describes frequent colonization of the oral cavity in healthy individuals without lesions, varying from $20 \%$ to $55 \%$ and in some cases $80 \%(2,3,6,9)$. In the present study, $71.42 \%$ of the individuals presented Candida and these data are in accordance with previous studies.

From the 49 strains isolated, $30(61.22 \%)$ were $C$. albicans, followed by $C$. tropicalis $(20.42 \%)$, C. glabrata $(6.12 \%)$ and $C$. kefyr $(2.04 \%)$. Jorge et al. (8) reported the presence of C. albicans in saliva of $27.6 \%$ of the 428 studied individuals ( 17 to 23 years old) and in $33.1 \%$ of children from 3 to 14 years old. In the present study, the number of individuals with Candida spp. was higher in relation to all the groups described by these authors. The highest percentage of Candida spp. isolation in this study can be mainly related to the collection method used in this study (oral rinses).

C. tropicalis can cause invasive and nosocomial candidosis (14) and is considered an opportunistic pathogen in immunocompromised patients (6). C. tropicalis can be found in routine cultures from the nose, throat, skin, vagina and digestive tract (10). In this work, C. tropicalis was the second most frequently isolated specie. Paula et al. (19) reported that $16 \%$ of the isolates from the oral cavity of patients with cancer during radiotherapy belonging to the genus Candida were identified as $C$. tropicalis. This result is similar to the value obtained in this study (20.42\%), despite the absence of such predisposing factor among the patients. Three strains $(6.12 \%)$ were identified as C. glabrata. According to Larone (12), approximately $7 \%$ of the oral isolates are C. glabrata. C. glabrata is also related with endocarditis and systemic fungemia (10).

Among the studied isolates only one (2.04\%) was identified as $C$. kefyr. Five strains isolated from the oral rinses could not be identified through biochemical tests and were considered Candida spp. 
Among the Candida spp. virulence factors, proteinase and phospholipase activities have been extensively studied as they can play an important role in the pathogenesis of the candidosis. The determination of the enzymatic activity of $C$. albicans and other species isolated from different anatomic sites was observed by several authors $(17,19,21,24)$. These studies showed a variation from 60 to $100 \%$ of isolates with proteinase activity and 50 to $100 \%$ for phospholipase activity. The results of the present work are in accordance with the percentages, since $60 \%$ of C. albicans strains produced phospholipase or presented proteinase activity.

Almeida (1) reported the production of phospholipase by $20 \%$ of C. guilliermondii strains. According to this author, C. krusei, C. parapsilosis and C. tropicalis did not produce phospholipase. In this study, among the 10 isolates of $C$. tropicalis, four presented strong phospholipase activity.

In the present study, six different killer biotypes could be obtained $(111,114,116,411,443,888)$. The biotype 111 was the most frequent. Polonelli et al. (23) obtained 25 different biotypes among 100 strains, and the biotype 111 was also the most prevalent. Magaró et al. (13) related 3 different killer biotypes (111,214 and 411).

In this work, six strains were classified as the killer biotype 888. This biotype is resistant to all the killer proteins. These data are very useful and interesting for epidemiological purposes as this biotype was isolated from the same institution and anatomical site.

Several studies reported that the anterior nares are the most frequent site where Staphylococcus spp. can be found (18). According to Suzuki et al. (28), the oral cavity can be a reservoir of $S$. aureus. Knighton (09) studied the presence of coagulasepositive staphylococci in the oral cavity and nose in Dental students and detected this microorganism in the saliva of $47.50 \%$ of the individuals and in the nasal fossae of $41.7 \%$ of them. According to this author, this correlation suggests that pathogenic staphylococci reservoir in the oral cavity are as important as those in the nasal fossae. Piochi and Zelante (20) detected S. aureus in $35 \%$ of the salivary samples and emphasized the importance of the oral cavity as a reservoir of pathogenic staphylococci. S. aureus was isolated from $13.9 \%$ of the oral rinses in this study.

The isolation of S. hyicus (17\%) and S. schleiferi subspecie coagulans $(6.1 \%)$ was interesting, since there is no study in the literature describing the presence of these species in the human oral cavity.

Coagulase-negative staphylococci were found in $63 \%$ of the oral cavities. Although, being considered microorganisms with little clinical importance for many years, nowadays they are associated to several human diseases (11), such as urinary infections, endocarditis, cardiac valvula infections, osteomyelitis, endolphtalmitis and nosocomial infections (25). In the last ten years, the incidence of bacteremia caused by coagulase-negative staphylococci has increased dramatically. Approximately half of the deaths associated with bacteremia are caused by coagulase-negative staphylococci.

Candida spp. and Staphylococcus spp. have been increasingly reported as potential opportunistic pathogens, involved in superinfection cases. In this way, more studies on their virulence, pathogenicity and correlation with other pathogens are very important.

\section{ACKNOWLEDGEMENTS}

We thank Dr. Ivan Balducci for the statistical analysis.

\section{RESUMO}

\section{Presença de Staphylococcus spp. e Candida spp. na cavidade bucal humana}

A presença de leveduras do gênero Candida e Staphylococcus na cavidade bucal humana é de extrema importância, pois podem atuar como microbiota suplementar e em determinadas situações causar doença bucal ou sistêmica. O objetivo do presente trabalho foi estudar a prevalência de Candida spp. e Staphylococcus spp. na cavidade bucal humana. Enxagüe bucal foi coletado de 68 indivíduos segundo a técnica proposta por Samaranayake e MacFarlane e a seguir semeados em ágar Sabouraud dextrose com cloranfenicol e ágar BairdParker. Após crescimento, os microrganismos foram isolados e identificados através de provas bioquímicas. Os dados foram analisados através de análise de variância (ANOVA). Leveduras do gênero Candida foram encontradas em $61,76 \%$ dos indivíduos examinados, sendo C. albicans a mais frequentemente isolada. Staphylococcus spp. foram isolados em $95,60 \%$ das cavidades bucais, sendo 41 cepas (63\%) coagulase-negativas. Das cepas coagulase-positivas, nove eram $S$. aureus, $11 S$. hyicus, e quatro $S$. schleiferi subespécie coagulans. Não foi observada correlação entre as contagens (UFC) de Candida spp. e Staphylococcus spp. encontradas nos enxagües bucais dos indivíduos examinados.

Palavras-chave: Staphylococcus, Candida, fosfolipase, proteinase, sistema killer, cavidade bucal.

\section{REFERENCES}

1. Almeida, N.Q. Influência da produção de hialuronidase, proteinase, condroitin-sulfatase e fosfolipase por algumas espécies de Candida sobre a patogenicidade para camundongos. São José dos Campos, 1991, 111p. (Livre Docência Thesis. Faculdade de Odontologia de São José dos Campos, UNESP).

2. Arendorf, T.M.; Walker, D.M. Oral candidal populations in health and disease. Br. Dent. J., 147: 267-272, 1979.

3. Brawner, D.L.; Cuttler, J.E. Oral Candida albicans isolates from nonhospitalized normal carriers, immunocompetent hospitalized 
patients, and immunocompromised patients with or without acquired immunodeficiency syndrome. J. Clin. Microbiol., 27: 1335-1341, 1989.

4. Cannon, R.D.; Holmes, A.R.; Mason, A.B.; Monk, B.C. Oral Candida: clearance, colonization, or candidiasis? J. Dent. Res., 74: 1152$1161,1995$.

5. Forbes, B.A.; Sahm, D.F.; Weissfeld, A.S. Staphylococcus, micrococcus, and similar organisms. In: Bailey \& Scott's diagnostic microbiology, St. Louis, Mosby, 1998, p.602-618.

6. Gelfand, M.S. Candida tropicalis. Infect. Control Hosp. Epidemiol., 10: 280-283, 1989.

7. Helovuo, H.; Hakkarainen, K.; Paunio, K. Changes in the prevalence of subgingival enteric rods, staphylococci and yeasts after treatment with penicillin and erythromycin. Oral Microbiol. Immunol., 8: 7579, 1993.

8. Jorge, A.O.C.; Koga-Ito, C.Y.; Gonçalves, C.R.; Fantinato, V.; Unterkircher, C.S. Presença de leveduras do gênero Candida na saliva de pacientes com diferentes fatores predisponentes e de indivíduos controle. Rev. Odontol. Univ. São Paulo, 11: 279-285, 1997.

9. Knighton, H.T. Coagulase-positive Staphylococci in oral and nasal áreas of dental students: a four-year study. J. Dent. Res., 44: 467$470,1965$.

10. Komshian, S.V.; Uwaydah, A.K.; Sobel, J.D.; Crane, L.R. Fungemia caused by Candida species and Torulopsis glabrata in the hospitalized patient: Frequency, characteristics and evaluation of factors influencing outcome. Rev. Infect. Dis., 2: 379-390, 1989.

11. Koneman, E.; Allen, S.D.; Janda, W.M.; Schreckenberger, P.C.; Junior, W.C.W. The Gram-Positive Cocci: In: Color atlas and textbook of diagnostic microbiology. 5.ed. Lippincott - Raven, Washington, 1997, p.539-575.

12. Larone, D.H. Yeast and yeastlike organism. In: Medically important fungi: a guide to identification. ASM Press, Washington, 1995, p.61-83.

13. Magaró, H.M.; Biasoli, M.S.; Bracalenti, B.J.C. Sistema "killer" em cepas de Candida albicans. Bol. Micol., 4: 73-76, 1989.

14. Marina, N.M.; Flynn, P.M.; Riveira, G.K.; Hunghes, W.T. Candida tropicalis and Candida albicans. Fungemia in children with leukemia. Cancer, 68: 594-599, 1991.

15. Neville, B.W.; Damm, D.D.; Allen, C.M.; Bouquot, J.E. Fungal and protozoal diseases. In: Oral \& maxillofacial pathology. Saunders, Philadelphia, 1995, p.163-180.
16. Öhman, S.C.; Jontell, M. Treatment of angular cheilitis. Acta Odontol. Scand., 46: 267-272, 1988.

17. Oliveira, E.E.; Silva, S.C.; Soares, Ailton, A.J.; Attux, C.; Cruvinel, B.; Silva, M.R.R. Toxinas killer e produção de enzimas por Candida albicans isoladas da mucosa bucal de pacientes com câncer. Rev. Soc. Bras. Med. Trop., 31: 523-27, 1998.

18. Parras, F.; Guerrero, M.C.; Bouza, E.; Blázquez, M.J.; Moreno, Santiago.; Menargues, M.C.; Cercenado, E. Comparative study of mupirocin and oral co-trimoxazole plus tropical fusidic acid eradicatron of nasal carriage of methicillin-resistant Staphylococcus aureus. Antimicrob. Agents. Chemother., 39: 175-179, 1995.

19. Paula, C.R.; Sampaio, M.C.; Birman, E.G.; Siqueira, A.M. Oral yeasts in patients with cancer of the mouth, before and during radiotherapy. Mycopathologia, 112: 119-124, 1990.

20. Piochi, B.J.A.; Zelante, F. Contribuição para o estudo de Staphylococcus isolados da cavidade bucal. I - Staphylococcus isolados da saliva. Rev. Fac. Odontol. São Paulo, 11: 367-378, 1973.

21. Pires, M.F.C.; Birman, E.G.; Costa, C.R.; Gambale, W.; Paula, C.R. Candida albicans byotipes isolated from the oral cavity of HIVpositive patients. Rev. Microbiol., 27: 46-51, 1996.

22. Polonelli, L.; Archibusacci, C.; Sestito, M.; Morace, G. Killer system: a simple method for differentiating Candida albicans strains. J. Clin. Microbiol., 17: 774-780, 1983.

23. Price, M.F.; Wilkinson, I.D.; Gentry, L.O. Plate method for detection of phospholipase activity in Candida albicans. Sabouraudia., 20: 7-14, 1982.

24. Rüchel, R.; Tegeler, R.; Trost, M. A comparison of secretory proteinases from different strains of Candida albicans. Sabouraudia, 20: 233-244, 1982.

25. Rupp, M.E.; Archer, G.L. Coagulase-negative staphylococci: pathogens associated with medical progress. Clin. Infec. Dis., 19: 231-245, 1994.

26. Samaranayake, L.P.; MacFarlane, T.W. Oral candidosis. Wright, London, 1990.

27. Sandvén, P. Laboratory identification and sensitivity testing of yeast isolates. Acta Odontol Scand., 48: 27-36, 1990.

28. Suzuki, J.; Komatsuzawa, H.; Sugai, M.; Suzuki, T.; Kozai, K.; Miyaki, Y.; Suginaka, H.; Nagasaka, N. A long-term of methicillin-resistant Staphylococcus aureus in the oral cavity of children. Microbiol. Immunol., 41: 681-686, 1997. 